\title{
Fiscal Decentralization and Economic Growth: A Cross-Country Study*
}

\author{
H amid D avoodi and H eng-fu Z ou
}

Policy Research Department, The World Bank, N10-075, 1818 H St. NW, Washington, DC 20433; and Institute of Advanced Studies, Wuhan University, Wuhan, China 430072

R eceived M ay 14, 1996; revised J anuary 31, 1997

\begin{abstract}
We use a panel data set of 46 countries over the 1970-1989 period to investigate the relationship between fiscal decentralization and economic growth. We find a negative relationship between fiscal decentralization and growth in developing countries, but none in developed countries. Several explanations are offered for our findings. (c) 1998 A cademic Press
\end{abstract}

\section{INTRODUCTION}

$O$ ut of the seventy-five developing and transitional economies with populations greater than five million, all but twelve claim to have embarked on some type of transfer of power to local governments (Dillinger [7]). Fiscal decentralization, or the devolution of fiscal power from the national government to subnational governments, is seen as part of a reform package to improve efficiency in the public sector, to increase competition among subnational governments in delivering public services, and to stimulate economic growth (Bahl and Linn [1], Bird and Wallich [4]).

The basic economic argument in favor of fiscal decentralization is based on two complementary assumptions: (1) decentralization will increase economic efficiency because local governments are better positioned than the national government to deliver public services as a result of information advantage; and (2) population mobility and competition among local governments for delivery of public services will ensure the matching of preferences of local communities and local governments (Tiebout [15];

\footnotetext{
*For criticisms, suggestions and help, we thank Richard Bird, Jan Brueckner, Shantayanan D evarajan, A ndrew F eltenstein, A vner G reif, Bert $\mathrm{H}$ ofman, G regory Ingram, R onald M CK innon, Charles MCLure, Wallace Oates, Y ingyi Qian, A nwar Shah, Hedy Sladovich, Barry W eingast, D anyang $X$ ie, T ao Z hang, and seminar participants at Stanford U niversity, W uhan U niversity, and the World Bank. We are most grateful to two referees and J an Brueckner for their detailed suggestions, which led to a substantial revision of this paper.
} 
0 ates [11]). These public-finance considerations suggest that policies aimed at the provision of public services such as infrastructure and education that are sensitive to regional and local conditions are likely to be more effective in encouraging growth than centrally-determined policies that ignore these geographical differences. Consequently, other things being equal, a decentralized fiscal system where local governments play a more important role than the federal or central government in public-service provision leads to more rapid economic growth (0 ates [13]).

A Ithough many policy discussions have favored decentralization, there is little empirical support to the hypotheses mentioned above. The objectives of our study are to supply an analytical framework and empirical methodology, and to use the methodology to test for the presence and size of efficiency gains from fiscal decentralization.

Fiscal decentralization is a complicated phenomenon with many dimensions. This paper will focus on one important dimension: economic growth. Section 2 provides a tractable theoretical and empirical framework linking fiscal decentralization to growth, and characterizes parameters that measure the efficiency gains from fiscal decentralization. The growth dimension of fiscal decentralization is emphasized for two reasons. First, economic growth is often cited as a major objective of fiscal decentralization (B ahl and Linn [1], Bird and W allich [4], $O$ ates [13]). Second, an often-stated objective of many governments is to adopt policies that lead to a sustained increase in per capita income. In that context, it is important to know which level of government (national or subnational) contributes more to economic growth.

Section 3 provides a detailed empirical examination of the relationship between fiscal decentralization and economic growth. Section 4 concludes and points to some limitations of the study.

\section{ANALYTICAL FRAMEWORK}

In this section, we outline a theoretical model of fiscal decentralization and economic growth. The model assumes, without loss of generality, three levels of government: federal, state, and local. The level of fiscal decentralization is defined as the spending by subnational governments as a fraction of total government spending. For example, fiscal decentralization increases if spending by state and local governments rises relative to spending by the federal government.

Following Barro [3], the production function has two inputs: private capital and public spending. We depart from the Barro model by assuming that public spending is carried out by three levels of government: federal, state, and local. Let $k$ be private capital stock, $g$ total government spending, $f$ federal government spending, $s$ state government spending, 
and $l$ local government spending, all measured on a per capita basis:

$$
f+s+l=g .
$$

The production function is Cobb-D ouglas ${ }^{1}$ :

$$
y=k^{\alpha} f^{\beta} s^{\gamma} l^{\omega},
$$

where $y$ is per capita output, $1>\alpha>0,1>\beta>0,1>\gamma>0,1>\omega>0$, and $\alpha+\beta+\gamma+\omega=1$.

The allocation of consolidated or total government spending $g$ among different levels of government takes the following form:

$$
f=\theta_{f} g, \quad s=\theta_{s} g, \quad l=\theta_{l} g,
$$

where $\theta_{f}+\theta_{s}+\theta_{l}=1$ and $0<\theta_{i}<1$ for $i=f$, $s$, and $l$. Thus, $\theta_{f}$ is the share of federal government in total spending, $\theta_{s}$ the share of state government, and $\theta_{l}$ the share of local government. Consolidated government spending $g$ is financed by a flat income tax at rate $\tau$ :

$$
g=\tau y .
$$

The representative agent's preferences are given by

$$
U=\int_{0}^{\infty} \frac{c^{1-\sigma}-1}{1-\sigma} e^{-\rho t} d t
$$

where $c$ is per capita private consumption, and $\rho$ is the positive time discount rate.

The dynamic budget constraint of the representative agent is

$$
\frac{d k}{d t}=(1-\tau) y-c=(1-\tau) k^{\alpha} f^{\beta} s^{\gamma} l^{\omega}-c .
$$

We further assume a constant tax rate along the balanced growth path. Given total government spending $g$, a constant tax rate $\tau$, and the shares of spending by different levels of governments $\left(\theta_{i}{ }^{\prime} s, i=f, s, l\right)$, the representative agent's choice of consumption is determined by maximizing (2.5) subject to (2.6) and the government's budget allocation. A long the balanced growth path, the solution for the per capita growth rate of the

${ }^{1}$ The use of more general functional forms such as the CES would not alter our analysis qualitatively; see Davoodi, X ie, and Zou [5] and Devarajan, Swaroop, and Zou [6]. 
economy is given by

$$
\frac{d y / d t}{y}=\frac{1}{\sigma}\left[(1-\tau) \tau^{1-\alpha / \alpha} \alpha \theta_{f}^{\beta / \alpha} \theta_{s}^{\gamma / \alpha} \theta_{l}^{\omega / \alpha}-\rho\right] .
$$

E quation (2.7) ${ }^{2}$ shows that the long-run growth rate of per capita output is a function of the tax rate and the shares of spending by different levels of government. It forms the basis for our empirical investigation of the relationship between fiscal decentralization and growth. Following the literature on fiscal federalism, we regard a country as more fiscally centralized if it has a higher value of the federal spending share $\theta_{f}$.

It is important to note that, for a given share of total government spending in GDP, a reallocation of public spending among different levels of governments can lead to higher economic growth if the existing allocation is different from the growth-maximizing expenditure shares. To show this point, we maximize the growth rate in (2.7) by choosing $\theta_{f}, \theta_{s}$, and $\theta_{l}$ subject to the constraint $\theta_{f}+\theta_{s}+\theta_{l}=1$. The growth-maximizing government budget shares are

$$
\theta_{f}^{*}=\frac{\beta}{\beta+\gamma+\omega}, \quad \theta_{s}^{*}=\frac{\gamma}{\beta+\gamma+\omega}, \quad \theta_{l}^{*}=\frac{\omega}{\beta+\gamma+\omega} .
$$

Therefore, as long as the actual government budget shares are different from growth-maximizing shares, the growth rate can always be increased without altering the total budget's share in GDP.

\section{EMPIRICAL ANALYSIS}

\subsection{Econometric Specification and Data Sources}

Equation (3.1) is the growth regression that will be estimated on a cross-country panel data using the ordinary least squares technique:

$$
g_{i t}=\delta_{1}+\delta_{2} \theta_{i t}+\delta_{3} \tau_{i t}+\delta_{4}^{\prime} D_{i}+\delta_{5}^{\prime} N_{t}+\delta_{6}^{\prime} X_{i t}+\varepsilon_{i t},
$$

where $i(=1, \ldots, I)$ and $t(=1, \ldots, N)$ refer to country $i$ at time $t ; I$ denotes the number of countries and $N$ the number of time periods; $\delta_{1}$, $\delta_{2}$, and $\delta_{3}$ are scalar parameters while $\delta_{4}^{\prime}, \delta_{5}^{\prime}$ and $\delta_{6}^{\prime}$ are vectors; $g_{i t}$ is the average growth rate; $\theta_{i t}$ is the measure of fiscal decentralization; $\tau_{i t}$ is the tax rate; $D_{i}$ is a vector of $I-1$ country fixed-effects (i.e., country dummies); $N_{t}$ is a vector of $N-1$ time fixed-effects (i.e., intercept time dummies). We work with time-averaged data since the benefits of fiscal

\footnotetext{
${ }^{2}$ See D avoodi, X ie, and Z ou [5] for a more general expression of the balanced growth rate with the CES production technology.
} 
decentralization are not expected to affect year-to-year fluctuations in growth. Because of our focus on long-run growth, the growth regression is estimated on data averaged over five- and ten-year periods. ${ }^{3}$ A ccordingly, the dependent variable is the average growth rate over these two periods; $X_{i t}$ is a vector of control variables; and $\varepsilon_{i t}$ is the disturbance term that is assumed to be serially uncorrelated and orthogonal to the explanatory variables. O ur primary concern is the coefficient $\left(\delta_{2}\right)$ on the fiscal decentralization variable, which is expected to be positive and significant given the conventional arguments in favor of fiscal decentralization.

The average growth rate is the average growth of real per capita output over five- and ten-year periods. Real per capita output is the real per capita gross domestic product (GDP) at 1985 international prices and is taken from the Summers-H eston [14] data set (version 5.6a). The tax rate is the ratio of total tax revenues to GDP, both in nominal terms and in local currency; these variables are taken from the International M onetary Fund's Government Finance Statistics (GFS) and the World Bank Economic and Social Data (BESD) base, respectively.

The measure of fiscal decentralization is the subnational share of total government spending. The higher is this measure, the higher is the degree of fiscal decentralization. Such a measure has been constructed previously by, inter alia, 0 ates $[12,13]$. The numerator of the fiscal decentralization variable is direct spending by subnational governments, i.e., their total spending net of intergovernmental transfers. The denominator is the sum of spending by the national government (i.e., the consolidated central government) and subnational governments (state and local) net of intergovernmental transfers. The GFS is the primary source for internationally comparable data on economic activities at all levels of government. To increase the sample size, for countries with three levels of government we have consolidated accounts of the two subnational governments (state and local governments) into one, thus enabling us to pool the fiscal decentralization measure for these countries with countries that have only one subnational government.

The vector $X_{i t}$ consists of a set of variables identified by Levine and Renelt [9] as the important control variables for cross-country growth regressions. These are (i) the average growth rate of population; (ii) initial human capital; (iii) initial per capita GDP; and (iv) the average real investment share of GDP. The first two variables are taken from the World Bank's BESD; the latter two are from the Summers-Heston data

\footnotetext{
${ }^{3}$ See Barro and Sala-i-M artin [2] for cross-country growth regressions on five- and ten-year average data.
} 
base. The measure of human capital is the secondary school enrollment rate; real investment's share of GDP refers to investment in physical capital.

After combining the above variables from various data sources, we obtain an unbalanced panel data set of 46 countries over the 1970-89 period. The Data A ppendix gives the list of countries included.

\subsection{Regression Results}

W e estimate regression (3.1) using (i) three country groupings-the full sample (world), developing and developed country samples; (ii) five- and ten-year average data, and (iii) with and without the control variables. O ur baseline regression includes the first five regressors in (3.1): a constant, average tax rate, fiscal decentralization, country fixed effects, and time fixed-effects. We then look at the sign and significance of the coefficient on the fiscal decentralization variable as we sequentially add the control variables across the three country groupings. These regressions, therefore, provide a rich set of sensitivity analyses regarding the possible relationship between fiscal decentralization and growth. We have summarized all these regressions in two tables.

Tables 1 and 2 show that there is a negative relationship between fiscal decentralization and economic growth for five- and ten-year intervals in the world and developing country samples; the point estimate is statistically significant in a one-tail test at the $5 \%$ and $10 \%$ level for the world and the developing country samples respectively. For the world sample, the $t$-ratios are -2.00 (Table 1; column 5) and -1.85 (Table 2; column 5) while the $t$-ratios for developing countries are -1.48 (Table 1 ; column 5 ) and -1.72 ( $T$ able 2; column 5 ). The one-tail test is a suitable one because the hypothesis that fiscal decentralization leads to higher growth predicts a positive relationship. Clearly a negative relation is a rejection of this hypothesis at the stated significance levels. However, if we were agnostic and maintained a hypothesis of no relation, then we should employ a two-tail test. In such a case we would not be able to reject the hypothesis of no relation at the same significance levels.

With either the one- or two-tail test, the point estimate of fiscal decentralization is similar for both samples in the two tables. For example, a 10 percentage point increase in fiscal decentralization (well within its standard deviation of $18 \%$ ) in the world and developing country samples is associated with a reduction in the growth rate of $0.7-0.8$ percentage points. As a benchmark comparison, consider another growth-reducing policy experiment: an equivalent reduction in the investment-GDP ratio of 10 percentage points will lead to a much larger decline in the growth rate (2.3-3.2 percentage points in the world and developing country samples, respectively). 
TABLE 1

Five-Y ear A verages

D ep. V ar: Per Capita GDP G rowth

W orld sample

Indep. var.

(1)

(2)

(3)

(4)

(5)

\begin{tabular}{|c|c|c|c|c|c|}
\hline Constant & $\begin{array}{c}1.53 \\
(0.69)\end{array}$ & $\begin{array}{c}4.41 \\
(1.55)\end{array}$ & $\begin{array}{c}5.53 \\
(1.80)\end{array}$ & $\begin{array}{l}48.78 \\
(3.60)\end{array}$ & $\begin{array}{l}51.95 \\
(3.98)\end{array}$ \\
\hline A verage tax rate & $\begin{array}{l}-0.04 \\
(-0.58)\end{array}$ & $\begin{array}{l}-0.06 \\
(-0.85)\end{array}$ & $\begin{array}{l}-0.04 \\
(-0.49)\end{array}$ & $\begin{array}{l}-0.06 \\
(-0.81)\end{array}$ & $\begin{array}{l}-0.01 \\
(-0.14)\end{array}$ \\
\hline $\begin{array}{l}\text { Fiscal } \\
\text { decentralization }\end{array}$ & $\begin{array}{l}-0.07 \\
(-1.86)\end{array}$ & $\begin{array}{l}-0.07 \\
(-1.85)\end{array}$ & $\begin{array}{l}-0.06 \\
(-1.47)\end{array}$ & $\begin{array}{l}-0.06 \\
(-1.56)\end{array}$ & $\begin{array}{l}-0.08 \\
(-2.00)\end{array}$ \\
\hline D ummy for 1975-79 & $\begin{array}{l}-1.09 \\
(-2.02)\end{array}$ & $\begin{array}{l}-1.21 \\
(-2.24)\end{array}$ & $\begin{array}{l}-1.01 \\
(-1.58)\end{array}$ & $\begin{array}{l}-0.13 \\
(-0.20)\end{array}$ & $\begin{array}{l}-0.17 \\
(-0.26)\end{array}$ \\
\hline D ummy for $1980-84$ & $\begin{array}{l}-2.34 \\
(-4.00)\end{array}$ & $\begin{array}{l}-2.54 \\
(-4.28)\end{array}$ & $\begin{array}{l}-2.45 \\
(-3.23)\end{array}$ & $\begin{array}{l}-0.77 \\
(-0.87)\end{array}$ & $\begin{array}{l}-0.60 \\
(-0.71)\end{array}$ \\
\hline D ummy for $1985-89$ & $\begin{array}{l}-1.19 \\
(-1.91)\end{array}$ & $\begin{array}{l}-1.45 \\
(-2.26)\end{array}$ & $\begin{array}{l}-0.98 \\
(-1.09)\end{array}$ & $\begin{array}{c}0.99 \\
(0.95)\end{array}$ & $\begin{array}{c}1.39 \\
(1.36)\end{array}$ \\
\hline Population growth & & $\begin{array}{l}-1.14 \\
(-1.61)\end{array}$ & $\begin{array}{l}-1.43 \\
(-1.90)\end{array}$ & $\begin{array}{l}-1.93 \\
(-2.63)\end{array}$ & $\begin{array}{l}-2.91 \\
(-3.73)\end{array}$ \\
\hline $\begin{array}{l}\text { Initial human } \\
\text { capital }\end{array}$ & & & $\begin{array}{l}-0.04 \\
(-1.05)\end{array}$ & $\begin{array}{c}-0.04 \\
(-1.25)\end{array}$ & $\begin{array}{l}-0.06 \\
(-1.68)\end{array}$ \\
\hline $\begin{array}{l}\text { Initial per capita } \\
\text { GDP }\end{array}$ & & & & $\begin{array}{l}-5.86 \\
(-3.27)\end{array}$ & $\begin{array}{c}-6.17 \\
(-3.58)\end{array}$ \\
\hline $\begin{array}{l}\text { Investment share } \\
\text { of GDP }\end{array}$ & & & & & $\begin{array}{c}0.23 \\
(2.95)\end{array}$ \\
\hline$R$-square & 0.53 & 0.54 & 0.53 & 0.58 & 0.62 \\
\hline Obs & 158 & 157 & 145 & 145 & 145 \\
\hline No. of countries & 46 & 45 & 43 & 43 & 43 \\
\hline$F$ value & 2.40 & 2.48 & 2.22 & 2.61 & 2.94 \\
\hline Prob $>F$ & 0.0001 & 0.0001 & 0.0005 & 0.0001 & 0.0001 \\
\hline
\end{tabular}

D eveloped countries

Indep. var.

(1)

(2)

(3)

(4)

(5)

\begin{tabular}{lccccc}
\hline Constant & 3.42 & 3.55 & 2.91 & 104.59 & 97.73 \\
& $(1.07)$ & $(1.01)$ & $(0.69)$ & $(4.89)$ & $(4.57)$ \\
A verage tax rate & -0.03 & -0.03 & -0.01 & -0.01 & -0.02 \\
& $(-0.54)$ & $(-0.54)$ & $(-0.20)$ & $(-0.18)$ & $(-0.38)$ \\
Fiscal & 0.01 & 0.01 & 0.02 & 0.04 & 0.04 \\
$\quad$ decentralization & $(0.18)$ & $(0.16)$ & $(0.42)$ & $(0.77)$ & $(0.77)$ \\
Dummy for 1975-79 & -1.16 & -1.17 & -1.46 & 0.25 & 0.46 \\
& $(-2.66)$ & $(-2.54)$ & $(-2.84)$ & $(0.45)$ & $(0.83)$ \\
Dummy for 1980-84 & -1.81 & -1.83 & -2.29 & 0.95 & 1.37 \\
& $(-3.40)$ & $(-3.23)$ & $(-3.51)$ & $(1.12)$ & $(1.57)$ \\
Dummy for 1985-89 & -0.28 & -0.29 & -0.64 & 3.44 & 3.86 \\
& $(-0.47)$ & $(-0.47)$ & $(-0.83)$ & $(3.29)$ & $(3.64)$ \\
Population growth & & -0.06 & -0.50 & -0.13 & -0.46 \\
& & $(-0.09)$ & $(-0.67)$ & $(-0.21)$ & $(-0.73)$ \\
\hline
\end{tabular}


TABLE 1

(Continued)

\begin{tabular}{|c|c|c|c|c|c|}
\hline Indep. var. & (1) & (2) & (3) & (4) & (5) \\
\hline $\begin{array}{l}\text { Initial human } \\
\text { Capital }\end{array}$ & & & $\begin{array}{l}-0.01 \\
(-0.25)\end{array}$ & $\begin{array}{c}-0.01 \\
(-0.57)\end{array}$ & $\begin{array}{c}-0.01 \\
(-0.72)\end{array}$ \\
\hline $\begin{array}{l}\text { Initial per capita } \\
\text { GDP }\end{array}$ & & & & $\begin{array}{l}-11.09 \\
(-4.82)\end{array}$ & $\begin{array}{l}-10.59 \\
(-4.65)\end{array}$ \\
\hline $\begin{array}{l}\text { Investment share } \\
\text { of GDP }\end{array}$ & & & & & $\begin{array}{c}0.12 \\
(1.62)\end{array}$ \\
\hline$R$-square & 0.58 & 0.58 & 0.60 & 0.75 & 0.76 \\
\hline Obs & 72 & 72 & 66 & 66 & 66 \\
\hline No. of countries & 19 & 19 & 18 & 18 & 18 \\
\hline$F$ value & 2.93 & 2.75 & 2.58 & 4.75 & 4.85 \\
\hline Prob $>F$ & 0.0008 & 0.0002 & 0.0036 & 0.0001 & 0.0001 \\
\hline \multicolumn{6}{|c|}{ D eveloping countries } \\
\hline Indep. var. & (1) & (2) & (3) & (4) & (5) \\
\hline Constant & $\begin{array}{c}3.46 \\
(1.14)\end{array}$ & $\begin{array}{c}8.40 \\
(2.06)\end{array}$ & $\begin{array}{c}9.75 \\
(2.14)\end{array}$ & $\begin{array}{l}63.76 \\
(3.25)\end{array}$ & $\begin{array}{l}69.64 \\
(3.76)\end{array}$ \\
\hline A verage tax rate & $\begin{array}{l}-0.17 \\
(-1.28)\end{array}$ & $\begin{array}{l}-0.19 \\
(-1.51)\end{array}$ & $\begin{array}{l}-0.17 \\
(-1.19)\end{array}$ & $\begin{array}{l}-0.25 \\
(-1.79)\end{array}$ & $\begin{array}{c}-0.14 \\
(-1.04)\end{array}$ \\
\hline $\begin{array}{l}\text { Fiscal } \\
\text { decentralization }\end{array}$ & $\begin{array}{l}-0.08 \\
(-1.46)\end{array}$ & $\begin{array}{l}-0.07 \\
(-1.36)\end{array}$ & $\begin{array}{l}-0.06 \\
(-1.11)\end{array}$ & $\begin{array}{l}-0.06 \\
(-1.18)\end{array}$ & $\begin{array}{l}-0.07 \\
(-1.48)\end{array}$ \\
\hline D ummy for $1975-79$ & $\begin{array}{l}-0.85 \\
(-0.91)\end{array}$ & $\begin{array}{l}-0.88 \\
(-0.96)\end{array}$ & $\begin{array}{l}-0.21 \\
(-0.18)\end{array}$ & $\begin{array}{c}0.91 \\
(0.79)\end{array}$ & $\begin{array}{c}0.40 \\
(0.37)\end{array}$ \\
\hline D ummy for $1980-84$ & $\begin{array}{l}-2.46 \\
(-2.55)\end{array}$ & $\begin{array}{l}-2.69 \\
(-2.81)\end{array}$ & $\begin{array}{l}-1.94 \\
(-1.42)\end{array}$ & $\begin{array}{c}0.10 \\
(0.07)\end{array}$ & $\begin{array}{l}-0.34 \\
(-0.25)\end{array}$ \\
\hline D ummy for $1985-89$ & $\begin{array}{l}-1.64 \\
(-1.64)\end{array}$ & $\begin{array}{l}-2.15 \\
(-2.11)\end{array}$ & $\begin{array}{l}-0.86 \\
(-0.51)\end{array}$ & $\begin{array}{c}1.13 \\
(0.66)\end{array}$ & $\begin{array}{c}1.22 \\
(0.75)\end{array}$ \\
\hline Population growth & & $\begin{array}{l}-2.00 \\
(-1.77)\end{array}$ & $\begin{array}{l}-2.17 \\
(-1.82)\end{array}$ & $\begin{array}{l}-3.33 \\
(-2.81)\end{array}$ & $\begin{array}{l}-4.81 \\
(-3.89)\end{array}$ \\
\hline $\begin{array}{l}\text { Initial human } \\
\text { capital }\end{array}$ & & & $\begin{array}{c}-0.07 \\
(-0.99)\end{array}$ & $\begin{array}{c}-0.07 \\
(-1.02)\end{array}$ & $\begin{array}{l}-0.09 \\
(-1.37)\end{array}$ \\
\hline $\begin{array}{l}\text { Initial per capita } \\
\text { GDP }\end{array}$ & & & & $\begin{array}{l}-7.08 \\
(-2.82)\end{array}$ & $\begin{array}{l}-7.69 \\
(-3.26)\end{array}$ \\
\hline $\begin{array}{l}\text { Investment share } \\
\text { of GDP }\end{array}$ & & & & & $\begin{array}{c}0.32 \\
(2.71)\end{array}$ \\
\hline$R$-square & 0.54 & 0.57 & 0.56 & 0.62 & 0.68 \\
\hline Obs & 86 & 85 & 79 & 79 & 79 \\
\hline No. of countries & 27 & 26 & 25 & 25 & 25 \\
\hline$F$ value & 2.04 & 2.23 & 1.91 & 2.37 & 2.84 \\
\hline Prob $>F$ & 0.0105 & 0.0051 & 0.0221 & 0.0036 & 0.0006 \\
\hline
\end{tabular}

Note: $t$-statistics are in parentheses. All regressions include country-specific dummies. 
TABLE 2

Ten-Y ear $A$ verages

D ep. V ar: Per Capita GD P G rowth

W orld sample

\begin{tabular}{lccccc} 
Indep. var. & $(1)$ & $(2)$ & $(3)$ & $(4)$ & $(5)$ \\
\hline Constant & 1.51 & 2.52 & 5.14 & 60.76 & 60.50 \\
& $(0.80)$ & $(0.89)$ & $(1.48)$ & $(4.56)$ & $(4.51)$ \\
A verage tax rate & -0.04 & -0.05 & -0.07 & -0.11 & -0.08 \\
& $(-0.48)$ & $(-0.54)$ & $(-0.72)$ & $(-1.36)$ & $(-0.91)$ \\
Fiscal & -0.10 & -0.10 & -0.09 & -0.07 & -0.07 \\
$\quad$ decentralization & $(-2.18)$ & $(-2.16)$ & $(-1.75)$ & $(-1.780)$ & $(-1.85)$ \\
D ummy for 1980-89 & -1.30 & -1.34 & -1.07 & 1.05 & 1.10 \\
& $(-2.84)$ & $(-2.85)$ & $(-1.66)$ & $(1.46)$ & $(1.51)$ \\
Population growth & & -0.41 & -1.14 & -2.65 & -2.74 \\
& & $(-0.48)$ & $(-1.16)$ & $(-3.03)$ & $(-3.08)$ \\
Initial human & & & -0.04 & -0.05 & -0.05 \\
$\quad$ capital & & & $(-1.05)$ & $(-1.72)$ & $(-1.75)$ \\
Initial per capita & & & & -7.09 & -7.12 \\
$\quad$ GD P & & & & $(-4.27)$ & $(-4.26)$ \\
Investment share & & & & & 0.06 \\
$\quad$ of GD P & & 0.75 & 0.75 & 0.84 & 0.85 \\
\hline$R$-square & 0.75 & 86 & 82 & 82 & 82 \\
O bs & & & 44 & 44 & 44 \\
N o. of countries & 46 & 45 & 2.33 & 3.53 & 2.42 \\
$F$ values & 2.38 & 0.0043 & 0.0128 & 0.0002 & 0.0002 \\
Prob $>F$ & 0.0033 & & & & \\
\hline
\end{tabular}

D eveloped countries

\begin{tabular}{lccccc} 
Indep. var. & $(1)$ & $(2)$ & $(3)$ & $(4)$ & $(5)$ \\
\hline Constant & -0.27 & -3.15 & -2.13 & 80.21 & 78.15 \\
& $(-0.05)$ & $(-0.56)$ & $(-0.32)$ & $(5.73)$ & $(5.14)$ \\
A verage tax rate & 0.09 & 0.13 & 0.14 & 0.11 & 0.10 \\
& $(0.85)$ & $(1.17)$ & $(1.13)$ & $(1.73)$ & $(1.60)$ \\
Fiscal & -0.04 & -0.02 & -0.01 & 0.05 & 0.05 \\
$\quad$ decentralization & $(-0.52)$ & $(-0.28)$ & $(-0.16)$ & $(1.37)$ & $(1.33)$ \\
Dummy for 1980-89 & -1.09 & -1.07 & -1.31 & 1.45 & 1.55 \\
& $(-1.77)$ & $(-1.75)$ & $(-1.87)$ & $(2.52)$ & $(2.44)$ \\
Population growth & & 1.14 & -0.11 & 0.06 & 0.05 \\
& & $(1.11)$ & $(-0.07)$ & $(0.08)$ & $(0.06)$ \\
Initial human & & & -0.02 & -0.02 & -0.02 \\
$\quad$ capital & & & $(-0.46)$ & $(-1.130)$ & $(-1.08)$ \\
Initial per capita & & & -9.07 & -8.92 \\
$\quad$ GD P & & & & $(-6.05)$ & $(-5.62)$ \\
Investment share & & & & $(0.03)$ \\
$\quad$ of GDP & & & & & $(0.46)$ \\
\hline
\end{tabular}


TABLE 2

(Continued)

\begin{tabular}{lccccc}
\hline Indep. var. & $(1)$ & $(2)$ & $(3)$ & $(4)$ & (5) \\
\hline$R$ square & 0.63 & 0.66 & 0.67 & 0.92 & 0.93 \\
O bs & 38 & 38 & 36 & 36 & 36 \\
N o. of countries & 19 & 19 & 19 & 19 & 19 \\
$F$ value & 1.31 & 1.323 & 1.083 & 5.647 & 5.04 \\
Prob $>F$ & 0.2937 & 0.2922 & 0.4596 & 0.0024 & 0.0055 \\
\hline
\end{tabular}

D eveloping countries

Indep. var.

(2)

(3)

(4)

(5)

\begin{tabular}{|c|c|c|c|c|c|}
\hline Constant & $\begin{array}{c}3.79 \\
(1.58)\end{array}$ & $\begin{array}{c}5.27 \\
(1.47)\end{array}$ & $\begin{array}{l}10.50 \\
(2.35)\end{array}$ & $\begin{array}{l}58.38 \\
(3.53)\end{array}$ & $\begin{array}{l}58.60 \\
(3.46)\end{array}$ \\
\hline A verage tax rate & $\begin{array}{l}-0.22 \\
(-1.64)\end{array}$ & $\begin{array}{l}-0.22 \\
(-1.64)\end{array}$ & $\begin{array}{l}-0.34 \\
(-2.35)\end{array}$ & $\begin{array}{c}-0.33 \\
(-2.82)\end{array}$ & $\begin{array}{l}-0.29 \\
(-2.17)\end{array}$ \\
\hline $\begin{array}{l}\text { Fiscal } \\
\text { decentralization }\end{array}$ & $\begin{array}{l}-0.11 \\
(-1.86)\end{array}$ & $\begin{array}{l}-0.11 \\
(-1.79)\end{array}$ & $\begin{array}{l}-0.09 \\
(-1.53)\end{array}$ & $\begin{array}{l}-0.08 \\
(-1.71)\end{array}$ & $\begin{array}{l}-0.08 \\
(-1.72)\end{array}$ \\
\hline D ummy for $1980-89$ & $\begin{array}{l}-1.56 \\
(-2.58)\end{array}$ & $\begin{array}{l}-1.64 \\
(-2.59)\end{array}$ & $\begin{array}{c}0.36 \\
(-0.37)\end{array}$ & $\begin{array}{r}-1.36 \\
(1.39)\end{array}$ & $\begin{array}{c}1.34 \\
(1.34)\end{array}$ \\
\hline Population growth & & $\begin{array}{l}-0.64 \\
(-0.57)\end{array}$ & $\begin{array}{c}-1.42 \\
(-1.22)\end{array}$ & $\begin{array}{l}-2.89 \\
(-2.69)\end{array}$ & $\begin{array}{l}-3.01 \\
(-2.69)\end{array}$ \\
\hline $\begin{array}{l}\text { Initial human } \\
\text { capital }\end{array}$ & & & $\begin{array}{l}-0.11 \\
(-1.82)\end{array}$ & $\begin{array}{l}-0.11 \\
(-2.19)\end{array}$ & $\begin{array}{l}-0.11 \\
(-2.12)\end{array}$ \\
\hline Initial per capita & & & & $\begin{array}{l}-6.15 \\
(-297)\end{array}$ & $\begin{array}{l}-6.26 \\
(-294)\end{array}$ \\
\hline $\begin{array}{l}\text { Investment share } \\
\text { of GDP }\end{array}$ & & & & & $\begin{array}{c}0.06 \\
(0.57)\end{array}$ \\
\hline$R$-square & 0.82 & 0.82 & 0.84 & 0.90 & 0.90 \\
\hline Obs & 49 & 48 & 46 & 46 & 46 \\
\hline No. of countries & 27 & 26 & 25 & 25 & 25 \\
\hline$F$ value & 2.92 & 2.83 & 2.99 & 4.60 & 4.26 \\
\hline Prob $>F$ & 0.0088 & 0.0121 & 0.0122 & 0.0015 & 0.003 \\
\hline
\end{tabular}

Note: $t$-statistics are in parentheses. All regressions include country-specific dummies.

As for other explanatory variables in the regressions, the average tax rate is negatively related to growth and quantitatively more significant for developing countries. This finding perhaps reflects the differential effects of distortionary taxation between the two sets of countries. Of the four other control variables, only human capital has the wrong (negative) sign; growth is higher in countries with a higher investment rate, lower population growth and lower initial per capita GDP. The negative coefficient on 
initial per capita GDP indicates the conditional convergence found in many previous studies, i.e., other things being equal, countries that start poorer tend to grow faster.

To sum up, regression results in Tables 1 and 2 show that (i) there is no relationship between fiscal decentralization and growth in developed countries, and (ii) the negative relationship between fiscal decentralization and growth is limited to the developing country sample, which seems to be driving the same results in the pooled world sample. To explain the difference, we note that in our panel data there is much more cross-country variation in growth and fiscal decentralization for developing countries than developed countries. The standard deviation of per capita output growth in developing countries is three times as high as that of developed countries; and the spread between the most and the least fiscally-decentralized developing country is 1.4 times as high as the spread in developed countries. Developed countries are simply too homogeneous vis-a-vis developing countries, leaving hardly any cross-country variation in fiscal decentralization to be linked systematically to cross-country differences in growth. Therefore, when the data for developing countries are pooled with developed countries, the variation in the former dominates that in the latter, producing a result for the world sample that closely resembles the developing country sample.

\subsection{Some Explanations of the Negative Effect of Fiscal Decentralization on}

\section{Growth in Developing Countries}

How can one explain the negative impact of fiscal decentralization on economic growth for developing countries? We offer several explanations. First, the composition of government spending may explain the negative finding. The decentralization measure in this study does not tell us what a subnational government buys; it does not distinguish between current spending (e.g., wages and salaries) and capital spending; nor does it distinguish spending on welfare and social security from infrastructure spending. The conventional wisdom points towards positive growth effects of capital and infrastructure spending and negative growth effects of welfare and current spending. Excessive spending by subnational governments on the wrong expenditure items can lead to lower growth even if the expenditure assignment is optimal. Second, lower growth can result from the wrong revenue assignment among various levels of government. For example, subnational governments may be raising revenues using a tax instrument which should have been used by the central government. Third, the efficiency gains from fiscal decentralization, perhaps the strongest 
argument in its favor, may not materialize for developing countries since revenue collection and expenditure decisions by local governments may still be constrained by the central government. Fourth, in practice local governments may not be responsive to local citizens' preferences and needs. This can occur when local officials are not elected by local citizens and when local citizens may be too poor to "vote with their feet."

\section{CONCLUSIONS}

In this paper we have provided a simple endogenous growth model showing how the degree of fiscal decentralization affects the growth rate of the economy. We used a cross-country panel data set of 46 developed and developing countries over the 1970-89 period to investigate whether fiscal decentralization has any growth impact. From our sample, developed countries are on average more decentralized than developing countries ( $33 \%$ vs. $20 \%$ ) and tend to have a higher per capita G DP growth rate $(2 \%$ vs. $1.6 \%)$. But can one conclude that there is a positive relationship between decentralization and growth? G iven other determinants of growth, we find a negative relationship for developing countries and the world, and none for developed countries. The point estimate for the developing country sample is significant at the $10 \%$ level in a one-tail test, which is an appropriate test under the null hypothesis that fiscal decentralization leads to higher growth. Therefore, on the basis of this test and the significance level we clearly reject the hypothesis of a positive relationship between fiscal decentralization and growth.

Finally, we want to draw attention to one major limitation of this preliminary study. Our measure of fiscal decentralization, which is the subnational government share of total government expenditure, may not reflect the subnational governments' autonomy in expenditure decisionmaking. As M usgrave [10] has pointed out, subnational governments that act as administrative agents of national governments do not necessarily reflect true expenditure decentralization. Further work will look into other related issues of fiscal decentralization such as local autonomy, local revenue collection, the composition of local spending, and intergovernmental transfers. ${ }^{4}$

\footnotetext{
${ }^{4}$ Some analyses in a dynamic framework can be found in Zou [18, 19].
} 


\section{APPENDIX}

List of the 46 Countries in the Sample

A rgentina
Chile
C zechoslovakia, Former
Finland
H ungary
Iceland
India
Indonesia
Iran, Islamic R epublic of
Israel
Italy
K enya
M alawi
M alaysia
M exico
N etherlands A ntilles
N orway
Paraguay
Philippines
R omania
Sweden
Thailand
U ruguay

Z imbabwe
B elgium
D enmark
F rance
I reland
L uxembourg
N etherlands
Portugal
U nited K ingdom
Poland
China
A ustralia
A ustria
Bolivia
B razil
Canada
Colombia
South A frica
Switzerland
U nited States
Germany
Spain
Y ugoslavia, Former Fed. R ep.

\section{REFERENCES}

1. R. Bahl and J. F. Linn, "U rban Public Finance in Developing Countries," New Y ork, Oxford U niver. Press (1992).

2. R. Barro and X. Sala-i-M artin, "E conomic G rowth," M cG raw-H ill, N ew Y ork (1995).

3. R. Barro, Government spending in a simple model of endogenous growth, Journal of Political Economy, 98, S103-S125 (1990).

4. R. Bird and C. Wallich, "Fiscal decentralization and intergovernmental relations in transition economies: Towards a systematic framework of analysis," Country Economics D epartment Working Paper, World Bank, Washington D.C. (1993).

5. H. Davoodi, D. Xie, and H. Zou, "Fiscal Decentralization and E conomic Growth in the U nited States," M imeo, Policy R esearch Department, World Bank (1995).

6. S. Devarajan, V. Swaroop, and H. Zou, The composition of public expenditure and economic growth, Journal of Monetary Economics, 37, 313-344 (1996).

7. W. Dillinger, Decentralization and its implications for urban service delivery," U rban M anagement and Municipal Finance Discussion Paper No. 16, The World Bank, W ashington D.C. (1994). 
8. International M onetary Fund, "G overnment Finance Statistics," Washington, DC.

9. R. Levine and D. Renelt, A sensitivity analysis of cross-country growth regressions, American Economic Review, 82, 942-963 (1992).

10. R. M usgrave, "The Theory of Public Finance, A Study in Public E conomy," M cG raw-H ill, N ew Y ork (1959).

11. W. O ates, "Fiscal Federalism," H arcourt Brace J ovanovich, N ew Y ork (1972).

12. W. Oates, Searching for Leviathan: An empirical analysis, American Economic Review, 75, 748-757 (1985).

13. W. Oates, Fiscal decentralization and economic development, National Tax Journal, XLVI, 237-243 (1993).

14. R. Summers and A. H eston, Summers-H eston D atabase, version 5.6a (1995).

15. C. Tiebout, A pure theory of local expenditures, Journal of Political Economy, 64, 416-424 (1956).

16. The World Bank, "World Bank E conomic and Social Database," Washington, DC.

17. T. Zhang and H. Zou, "Fiscal Decentralization, Public Spending and E conomic Growth in China," Journal of Public Economics, in press.

18. H. Z ou, D ynamic effects of federal grants on local spending, Journal of Urban Economics, 36, 98-115 (1994).

19. H. Zou, Taxes, federal grants, local public spending and growth, Journal of Urban Economics, 39, 303-317 (1996). 